\title{
A Leaf Spot and Blight of Greenhouse Tomato Seedlings Incited by a Herbaspirillum sp.
}

\author{
Aleksa Obradovic, Jeffrey B. Jones, Gerald V. Minsavage, and Ellen R. Dickstein, Department of Plant Pathol- \\ ogy, University of Florida, Gainesville 32611; and Timur M. Momol, North Florida Research and Education Center, \\ University of Florida, Quincy 32351
}

\begin{abstract}
Obradovic, A., Jones, J. B., Minsavage, G. V., Dickstein, E. R., and Momol, T. M. 2007. A leaf spot and blight of greenhouse tomato seedlings incited by a Herbaspirillum sp. Plant Dis. 91:886-890

A leaf spot and blighting were observed on leaves of tomato transplants from a producer in Florida in 2001 and 2002. A nonfluorescent bacterium was isolated consistently from affected tissue. The typical bacterium was a gram negative, strictly aerobic, slightly curved rod with one or two flagella. Sequence analysis of the $16 \mathrm{~S}$ rRNA indicated that two representative strains, F1 and SE1, had greater than $99 \%$ nucleotide sequence identity with Herbaspirillum huttiense and $H$. rubrisubalbicans. The cellular fatty acid composition of the total of 16 tomato strains was very similar to $H$. huttiense and $H$. rubrisubalbicans. Based on carbon utilization, six of nine strains tested with the Biolog system were identified as Herbaspirillum spp. The tomato strains were oxidase positive and grew at $40^{\circ} \mathrm{C}$, but were negative for levan production, pectate hydrolysis, and arginine dihydrolase activity. Based upon this polyphasic analysis, we concluded that the strains were most closely related to $H$. huttiense, although placement in this species would require further analyses. However, the tomato strains and $\mathrm{H}$. rubrisubalbicans, but not $\mathrm{H}$. huttiense, caused confluent necrosis when infiltrated at high concentrations into tomato leaves and were able to produce leaf spot symptoms on inoculated tomato seedlings in the greenhouse. Using pulsed-field gel electrophoresis, we determined that there was considerable variability between the strains collected in 2001 and 2002.
\end{abstract}

Additional key words: Bacterial spot, Pseudomonas huttiensis

In Florida, bacterial spot of tomato ( $S o$ lanum lycopersicum L.), caused by Xanthomonas euvesicatoria and $X$. perforans (15) (previously designated $X$. campestris pv. vesicatoria), is a major disease causing significant problems on tomato transplants as well as field-grown tomato. Tomato transplant production supplies virtually all plants to the $\$ 400$ million fresh-market tomato industry in Florida. As such, control measures are used to limit losses associated with this disease on transplants. Integrated with cultural practices and other foliar treatments, bacteriophages have been shown to effectively control bacterial spot, resulting in increased yields $(5,10,17)$.

Corresponding author: J. B. Jones

E-mail: jbjones@ufl.edu

Current address of Aleksa Obradovic: University of Belgrade, Faculty of Agriculture, Plant Pathology Department, Nemanjina 6, 11080 Belgrade-Zemun, Serbia.

Accepted for publication 31 January 2007.

doi:10.1094/PDIS-91-7-0886

(C) 2007 The American Phytopathological Society
Recently, bacteriophages received Environmental Protection Agency registration (EPA registration no. 67986-1) for use on tomato and, therefore, are currently being used in greenhouses and production fields in Florida to control bacterial spot.

In October 2001 and July 2002, a leaf spot and blight was observed on 3- to 4-

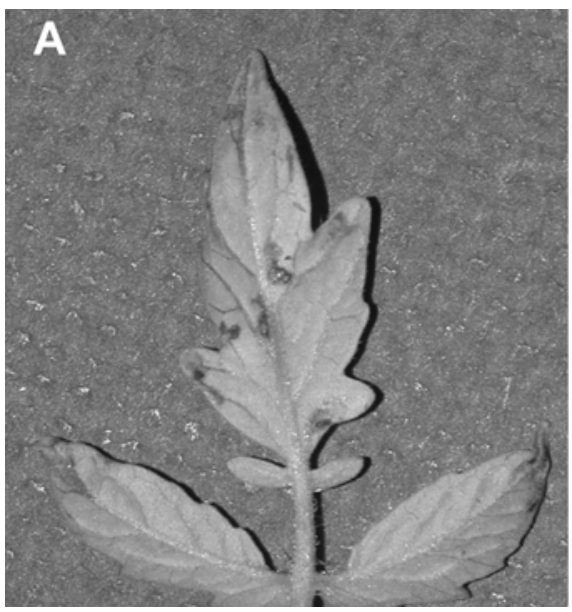

B

week-old tomato seedlings of a commercial cultivar grown for transplants in a greenhouse in southern Florida. The greenhouse operation had used bacteriophages as part of a strategy to control bacterial spot. The seedlings displayed various symptoms. Some plants showed discrete lesions along the leaf veins and isolated leaf spots (Fig. 1A). The spots were irregular and varied in size from 2 to $4 \mathrm{~mm}$. Affected tissue was discolored and necrotic (Fig. 1B). Most of the seedlings had apical or marginal leaf necrosis. The diseased tissue collapsed, turned brown, and necrotized. Blighting of younger plants resulted in those plants being discarded. The disease remained localized on individual plants or on plants within one tray. Symptom development stopped within a week of the initial appearance. The symptoms did not occur on older plants. Less than $5 \%$ of the plants grown in the greenhouse were affected. Due to concern of possible spread of pathogens on tomato transplants in the greenhouse and the unusual symptoms of the disease, we investigated the causal agent of the seedling leaf spot and marginal leaf necrosis. In this article, we describe the isolation and identification of the bacterium associated with this new disease of tomato seedlings.

Fig. 1. A, Leaf spot and $\mathbf{B}$, apical leaf necrosis of naturally infected tomato seedlings grown in the greenhouse. 


\section{MATERIALS AND METHODS}

Isolation. Diseased transplants were received in October 2001 and in July 2002. Lesions from leaves of the diseased trans-

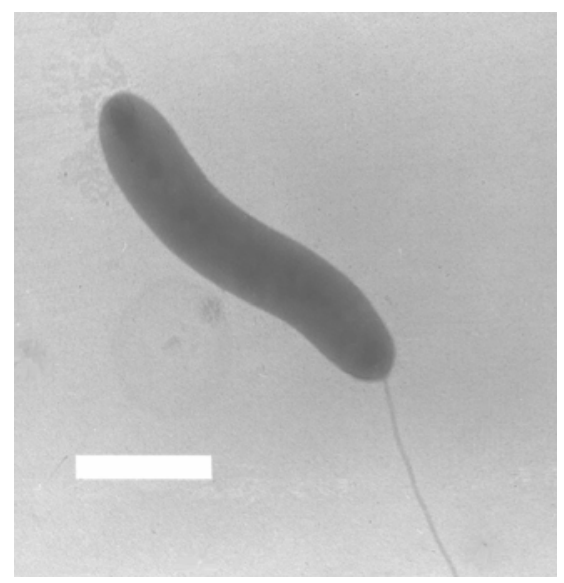

Fig. 2. A cell of representative strain SE1 with one polar flagella observed by transmission electron microscopy. The white bar represents $1 \mu \mathrm{m}$. plants were triturated in sterile tap water and the resulting suspensions were streaked onto nutrient agar (NA) plates. The plates were incubated at $28^{\circ} \mathrm{C}$ for 48 h. Representative colonies were transferred to new NA plates and used for further testing. Twelve strains were isolated from two samples received in 2001 and four strains from one sample obtained in 2002.

Physiological and biochemical tests. Characteristics of 16 strains isolated from diseased seedlings were determined using standard bacteriological tests, including gram reaction, production of a fluorescent pigment on King's medium B, oxidase reaction, levan production, pectate hydrolysis, arginine dihydrolase, and oxidative-fermentative $(\mathrm{O} / \mathrm{F})$ metabolism of glucose, as described by Schaad et al. (20). Carbon substrate utilization using Biolog GN MicroPlates (Biolog, Inc., Hayward, CA) was performed on nine strains representing isolations made in 2001 and 2002.

Cellular fatty acid composition of 16 tomato strains was determined and used to identify the pathogen. Bacteria were grown, extracted, and analyzed according to the standard Microbial Identification System (MIDI) protocol (MIDI, Newark, DE; 19). Extracts were analyzed using the Sherlock System. Results then were used to compare unknown strains with each other, with control strains, and with data from the MIDI database (MIDI Library Generation System version 4.5) in order to identify the pathogen.

Restriction endonuclease analysis. Genomic DNA of the bacterial strains was prepared and digested with SpeI as described by Egel et al. (9). The resulting large DNA fragments were separated by pulsed-field gel electrophoresis (PFGE). The gels were stained with ethidium bromide. All strains were run on the same gel so that accurate comparison could be made. SE1 and F1 were selected as representative strains based on their PFGE patterns.

Electron microscopy. Cells were grown in nutrient broth and incubated on a shaker

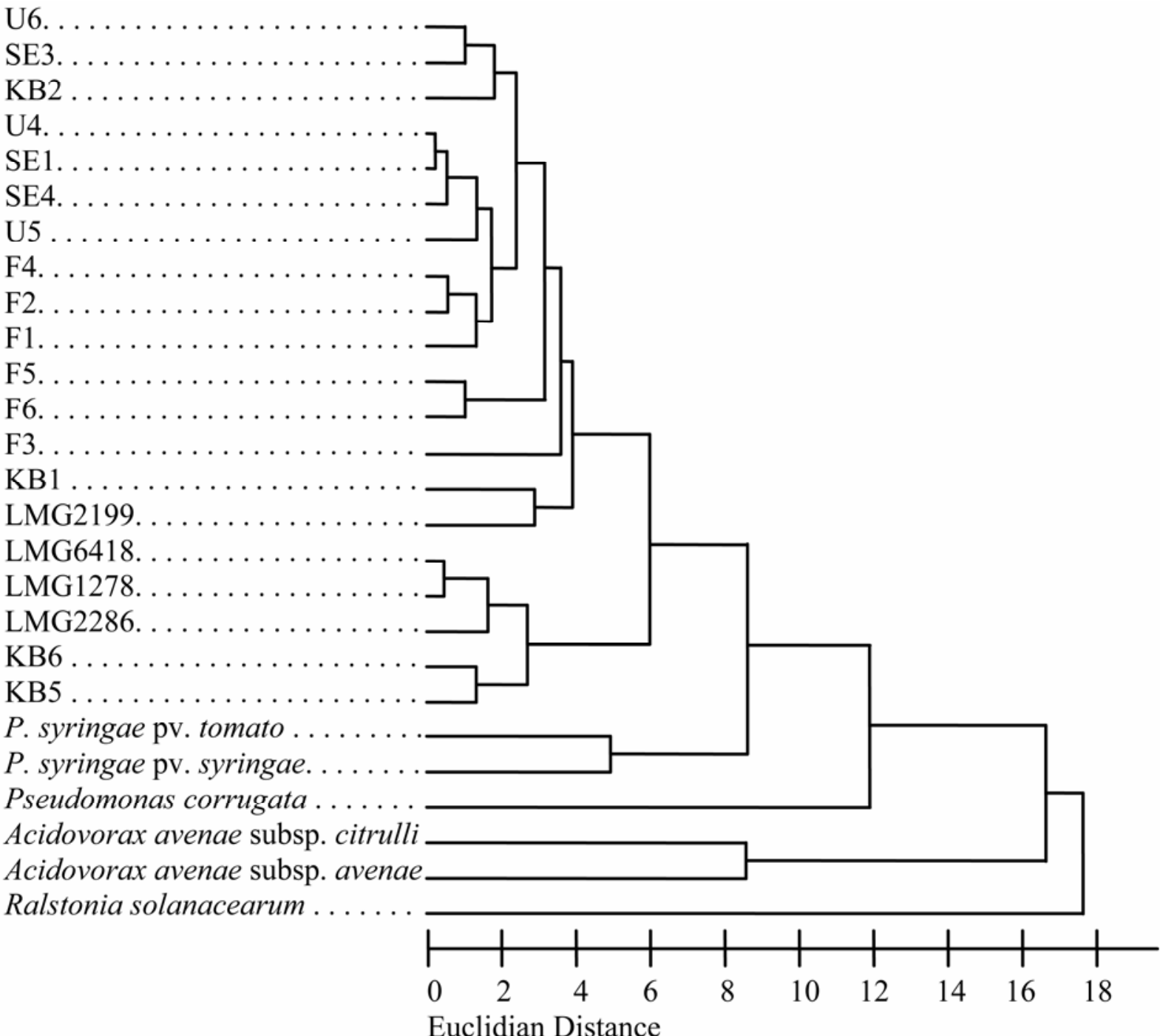

Fig. 3. Dendrogram representing cluster analysis based on fatty acid methyl ester profiles of tomato strains (F1, F2, F3, F4, F5, F6, SE1, SE3, SE4, U4, U5, U6, KB1, KB2, KB5, and KB6), control strains (Herbaspirillum rubrisubalbicans: LMG1278, LMG2286, and LMG6418; and H. huttiense: LMG2199) and data from the Microbial Identification System (MIDI) software database (MIDI Library Generation System version 4.5). 
at $28^{\circ} \mathrm{C}$ for $24 \mathrm{~h}$. A representative strain (SE1) was used and cell morphology was observed by transmission electron microscopy (TEM; 6).

Sequence analysis of $16 \mathrm{~S}$ rRNA. Amplification of the rrs (i.e., the 16S rRNA gene) and the intergenic spacer (IGS) located between $r r s$ and $r r l$ (i.e., the 23S rRNA gene) was performed under standard polymerase chain reaction (PCR) conditions using primers FGPS6-63 and FGPL132' as described by Ponsonnet and

Nesme (18). We sequenced the $16 \mathrm{~S}$ rRNA of two representative strains (SE1 and F1) and the sequences were compared in the GenBank, EMBL, and DJB databases using the gapped BLASTN 2.0.5 program through the National Center for Biotechnology Information server (1).

Pathogenicity and hypersensitive reaction tests. Hypersensitivity of the strains was tested by infiltration of bacterial suspensions $\left(10^{8} \mathrm{CFU} / \mathrm{ml}\right)$ in tomato leaves. Plants were incubated at approximately

Table 1. Composition of major fatty acids of selected strains isolated from tomato transplants and Herbaspirillum rubrisubalbicans and $H$. hutiense

\begin{tabular}{lrrcc}
\hline Fatty acid & SE1 & F1 & H. rubrisubalbicans & H. huttiense \\
\hline $10: 03 \mathrm{OH}^{\mathrm{a}}$ & 1.9 & 1.8 & 1.7 & 1.7 \\
$12: 0$ & 3.8 & 4.0 & 3.5 & 3.7 \\
$12: 03 \mathrm{OH}$ & 3.5 & 3.5 & 3.3 & 3.0 \\
14:0 $2 \mathrm{OH}$ & 2.7 & 2.9 & 2.3 & 2.6 \\
Sum feature $3^{\mathrm{b}}$ & 37.5 & 37.9 & 33.1 & 38.4 \\
16:0 & 23.7 & 23.0 & 25.8 & 26.5 \\
$17: 0$ cyclo & 2.4 & 1.9 & 5.4 & 1.7 \\
$18: 1 \omega 7 \mathrm{c}$ & 21.4 & 21.3 & 20.9 & 19.3 \\
\hline
\end{tabular}

a Only fatty acids with greater than $1 \%$ of total composition were included in this table.

${ }^{\text {b }}$ Sum feature 3 (15:0 ISO 2OH/16:1w7c).
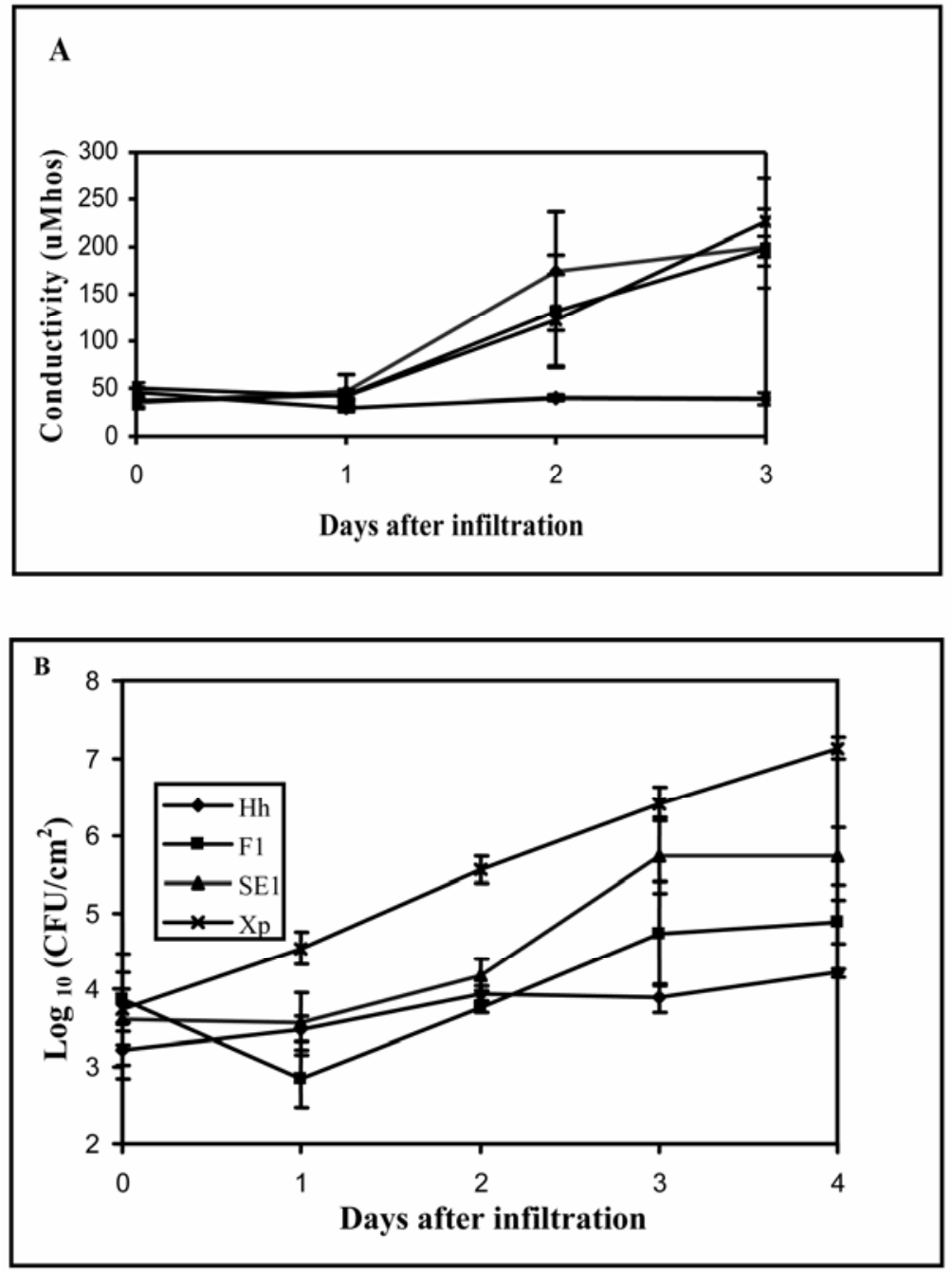

Fig. 4. A, Electrolyte leakage and $\mathbf{B}$, internal populations from leaf tissue of tomato cv. Bonny Best plants, infiltrated with suspension of two tomato strains (SE1 and F1), Herbaspirillum huttiense (Hh), and Xanthomonas perforans $(X p)$. $24^{\circ} \mathrm{C}$ and monitored for confluent necrosis for $48 \mathrm{~h}$.

In order to determine whether these strains induce a compatible or incompatible interaction in tomato leaflets, population dynamics and electrolyte leakage assays were performed. Six-week-old tomato plants (cv. Bonny Best) were infiltrated with bacterial suspensions $\left(10^{6}\right.$ and $10^{5} \mathrm{CFU} / \mathrm{ml}$, respectively) of two representative strains (SE1 and F1), a strain of Herbaspirillum huttiense (LMG2199), and a tomato race 3 strain of $X$. perforans (91118) and monitored for electrolyte leakage and population dynamics. Plants were incubated in a growth room at $28^{\circ} \mathrm{C}$ on a 12-h light cycle. Immediately after inoculation and subsequently for 3 days, samples of the infiltrated tissue were taken with a cork borer and the pathogen populations and electrolyte leakage were measured as previously described $(7,11)$.

In order to reproduce the symptoms of natural infection, 3-week-old tomato cv. Bonny Best seedlings were inoculated using two different methods. The first method consisted of spraying the plants with bacterial suspensions $\left(10^{8} \mathrm{CFU} / \mathrm{ml}\right)$ followed by incubation in high humidity conditions for $24 \mathrm{~h}$ in a growth chamber. The second method consisted of preincubating the tomato seedlings in high humidity provided by covering plants with plastic bags $24 \mathrm{~h}$ prior and after inoculation. The seedlings were inoculated by dipping the plants in bacterial suspension of the investigated strains $\left(10^{6} \mathrm{CFU} / \mathrm{ml}+\right.$ Silwet L77, $0.025 \%$ ) for $15 \mathrm{~s}$. Both sets of inoculated plants were removed from the highhumidity conditions and transferred to the greenhouse for symptom development. Diseased leaves of inoculated plants were used for reisolation of bacterial strains, as described previously. In both experiments, the same procedure was applied for control plants with no bacteria added to the treatment.

In order to evaluate disease severity, tomato cv. Florida 47 transplants were grown in $10-\mathrm{cm}$ pots containing commercial substrate (Floradur Anzuchterde, Typ-fein; Floragard Product Gartnererde, Germany). Prior to inoculation, 4-week-old plants were incubated in high humidity for $24 \mathrm{~h}$. Five plants per strain were inoculated by spraying with a hand-held plastic sprayer the bacterial suspensions (approximately $10^{8} \mathrm{CFU} / \mathrm{ml}$ ) of representative strains isolated from tomato (F1 and SE1) and control strains of $H$. rubrisubalbicans $\left(\mathrm{LMG}^{2} 286^{\mathrm{T}}=\right.$ ATCC 19308), H. huttiense $\left(\mathrm{LMG}_{2199^{\mathrm{T}}}=\right.$ ATCC 14670), and X. perforans (91-118) onto the foliage, followed by incubating under high humidity conditions for an additional $24 \mathrm{~h}$. Control plants were sprayed with sterile water. Both, inoculated and control plants were transferred to the greenhouse bench and spread out in a completely randomized design, followed by daily observation for symptom 
development. Disease severity was evaluated by estimating the leaf area affected with necrotic lesions using the HorsfallBarratt (HB) rating scale (12) 7 and 14 days after inoculation. The HB scale values were transformed to percent values and the data then were analyzed by using SAS software using analysis of variance (Proc ANOVA; SAS Institute, Cary, NC).

\section{RESULTS AND DISCUSSION}

Characterization of bacterial strains.

The consistent isolation of nonfluorescent bacterial strains forming creamy white colonies indicated that the bacterium was different from known pathogens causing symptoms on tomato foliage ( $X$. perforans, Pseudomonas syringae pv. tomato, $P$. syringae $\mathrm{pv}$. syringae, and $P$. viridiflava; 13 , 14). When observed by TEM, cells of the representative strain (SE1) were slightly curved, with one or two flagella on one or both poles (Fig. 2). The strains were gram negative, strict aerobes, and oxidase positive, and grew at $40^{\circ} \mathrm{C}$, but were negative for levan, pectate hydrolysis, and arginine dihydrolase. According to the fatty acid profiles, the strains displayed greatest similarity with the bacterium $P$. huttiensis (16), indicated as a first choice by MIDI system, with the similarity index ranging from 0.538 to 0.849 . Because this organism was proposed to be transferred to the genus Herbaspirillum $(2,3,8)$, we also included for comparison one $H$. huttiense

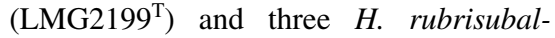
bicans (LMG2286 ${ }^{\mathrm{T}}$, LMG6418, and LMG1278) strains. When the data generated by fatty acid analysis were processed by MIDI software, the strains isolated from tomato and the control strains clustered into one group (Euclidean distance $\leq 6$ ), indicating a high degree of similarity in fatty acid composition (Fig. 3). However, within the group, the strains of $H$. rubrisubalbicans (LMG2286, LMG1278, and LMG6418) and two tomato strains formed a cluster or subgroup separate from $H$. huttiense (LMG2199) and 14 of the tomato strains which included SE1 and F1. The fatty acid composition of two representative tomato strains (SE1 and F1) was very close to $H$. rubrisubalbicans and $H$. huttiense (Table 1). The two tomato strains and $H$. huttiense had relatively low amounts of 17:0 cyclo and relatively high amounts of sum feature 3 compared with H. rubrisubalbicans. Results of PFGE showed that there was considerable variability in banding pattern between the strains collected in 2001 and 2002 (data not shown).

Based on differential oxidation of the 95 carbon substrates using the Biolog GN MicroPlate, five of the nine tested strains, including $\mathrm{F} 1$, were identified as $H$. huttiense and one as $H$. rubrisubalbicans, while the remaining three, including SE1, were most closely related to the carbon source utilization profile of genus Burkholderia saved in the database. The type strains of $H$. huttiense (LMG2199) and $H$. rubrisubalbicans (LMG2286) were identified correctly using the Biolog GN database.

Sequence analysis of the $16 \mathrm{~S}$ rRNA indicated that the two strains F1 (GenBank accession no. EF216331) and SE1 (GenBank accession no. EF216332) had 99.6\% homology between each other, 99.5 and $99.1 \%$ nucleotide sequence identity with H. huttiense (LMG2199 = ATCC 14670), and 99.8 and $99.3 \%$ nucleotide sequence identity with $H$. rubrisubalbicans (LMG 2286 = ATCC 19308), respectively.

Based on results of polyphasic analysis, the strains isolated from tomato transplants had greatest similarity with $H$. huttiense. The strongest evidence for the close relatedness of the tomato strains with this spe- cies is based on the 16S rRNA sequence analysis. Both strains had greater than $99 \%$ sequence identity with $H$. huttiense. Fatty acid analysis and Biolog also were useful for showing a closer relationship between the tomato strains and $H$. huttiense than with $H$. rubrisubalbicans.

Pathogenicity and hypersensitive tests. The tomato strains (SE1 and F1) and the $H$. rubrisubalbicans strain, when infiltrated at $10^{8} \mathrm{CFU} / \mathrm{ml}$ into tomato leaves, caused a hypersensitive reaction within 24 $\mathrm{h}$, whereas $X$. perforans caused tissue collapse after $48 \mathrm{~h}$ and the $H$. huttiense strain caused no symptoms. In the experiments where leaflets were infiltrated with bacterial suspensions adjusted to approximately $10^{6} \mathrm{CFU} / \mathrm{ml}$, the curves for electrolyte leakage for strains SE1 and F1 were similar to that of the bacterial spot pathogen, $X$. perforans. Electrolyte leakage basically remained unchanged in leaflets infiltrated with the $H$. huttiense strain (Fig. 4A). In population determinations where the bacterial suspensions were adjusted to $10^{5}$ $\mathrm{CFU} / \mathrm{ml}$ and infiltrated into tomato leaflets, the two tomato strains did not grow to the same level as the $X$. perforans strain, but reached levels at least 10 -fold lower (Fig. 4B). This may indicate that these strains are less virulent in tomato leaves. Again, the $H$. huttiense strain showed basically no multiplication in the infiltrated areas. Thus, the tomato strains acted like bacterial plant pathogens, whereas the known $H$. huttiense strain was typical of a nonpathogen.

In inoculation tests, only the strains isolated from tomato seedlings were able to produce symptoms similar to those observed in natural infection. Marginal tissue of leaves of inoculated plants collapsed and became necrotic 3 days after inoculation. Necrotic lesions occurred along the leaf margins. Small, pinpoint spots were

\section{Disease severity of inoculated tomato transplants}

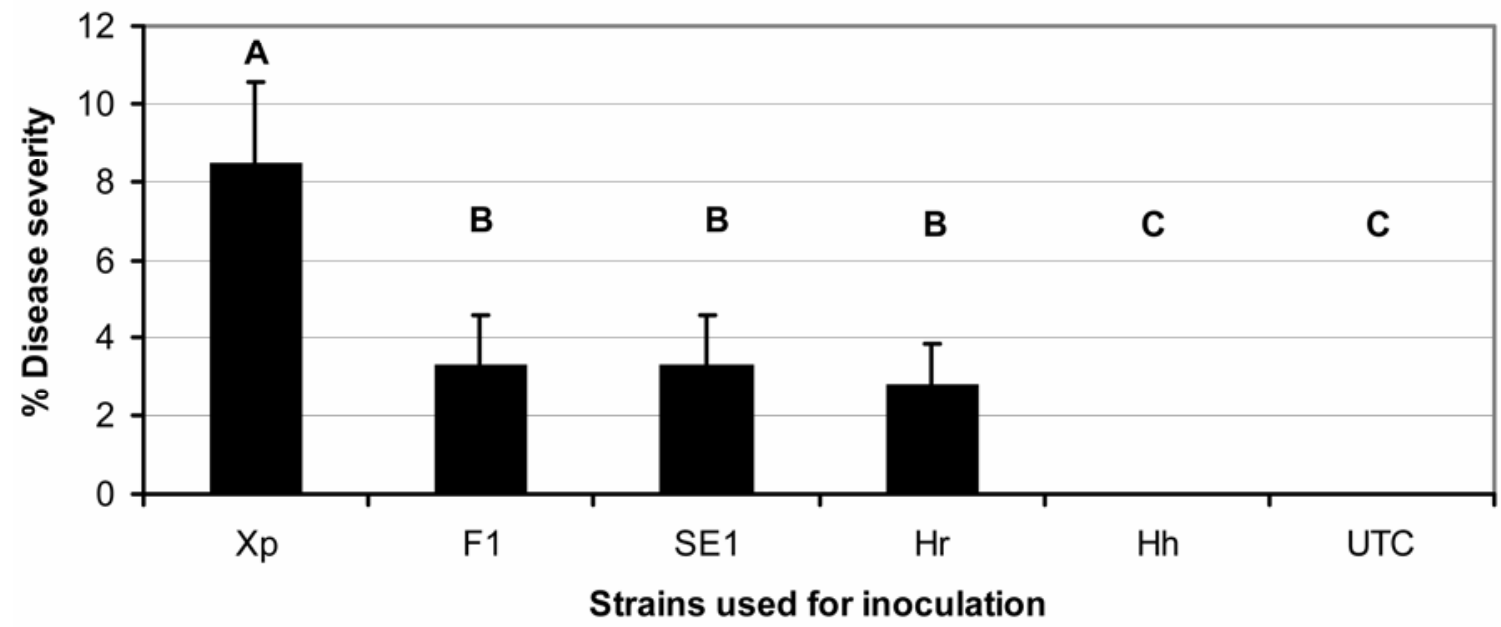

Fig. 5. Disease reaction of tomato transplants inoculated with Xanthomonas perforans (Xp; 91-118), tomato strains F1 and SE1, Herbaspirillum rubrisubalbicans (Hr; LMG2286), H. huttiense (Hh; LMG2199), and untreated control (UTC). The letter above the bars represents statistical difference between treatments according to Waller-Duncan's test. 
observed on the abaxial leaf surface 5 days after inoculation. The symptoms were more severe when a 24-h high-humidity incubation period preceded inoculation. Younger plants were more susceptible than older plants (data not shown). No secondary spread of symptoms was observed after the plants were transferred to the greenhouse. Based on population and electrolyte experiments, this organism was determined to be a weak pathogen. However, pathogenicity tests demonstrated that, under high-humidity conditions which exist in tomato transplant production, this weak pathogen was able to cause disease.

Statistical analysis of the disease severity data grouped the strains used for inoculation into three groups differing significantly in the severity of symptoms observed on tomato seedlings (Fig. 5). The known tomato pathogen $X$. perforans caused the strongest plant reaction observed 1 and 2 weeks after inoculation. The two tomato strains (F1 and SE1) and $H$. rubrisubalbicans strain also caused a leaf spot on inoculated transplants, although the severity was not as strong as on plants inoculated with $X$. perforans. $H$. huttiense was unable to produce any symptoms on the foliage (Fig. 5).

There are no records of $H$. huttiense being associated with plants. The type strain used for classification was isolated from distilled water (8). However, the endophytic occurrence of $H$. seropedicae and $H$. rubrisubalbicans was reported earlier (4). The habitat of $H$. seropedicae is roots, stems, and leaves of plants from the Gramineae family, whereas $H$. rubrisubalbicans seems to be limited to sugarcane (Saccharrum officinales), causing mottled stripe disease (3).

The origin of the strains associated with diseased tomato transplants is unknown. In the location where the transplants were produced, sugarcane was used as a windbreak. Given that $S$. officinales is a natural host for $H$. rubrisubalbicans and that the organism isolated from tomato was closely related to the sugarcane pathogen, it is plausible that sugarcane served as an inoculum source of the pathogen. Furthermore, it may be conceivable that $\mathrm{H}$. ru- brisubalbicans is heterogeneous and, in fact, may consist of at least two species of bacteria, with one including $\mathrm{H}$. rubrisubalbicans and the other representing the strains more closely related to $H$. huttiense. There is definite precedence for more than one bacterial species within a bacterial genus causing disease on the same host, as has been shown with xanthomonads in which four species cause bacterial spot on tomato plants (15), and with several fluorescent pseudomonads being associated with leaf spots or blighting of tomato foliage $(13,14)$.

\section{ACKNOWLEDGMENTS}

We thank M. Petersen for technical assistance in electron microscopy; and C. D. Jones, M. Stepanovic, and M. Djordjevic for their technical assistance with pathogenicity tests.

\section{LITERATURE CITED}

1. Altschul X., Stephen F., Thomas L, Madden, X., Alejandro A., Schaffer X., Zhang, J., Zhang, Z., Miller, W., and Lipman, D.J. 1997. Gapped BLAST and PSI-BLAST: a new generation of protein database search programs. Nucleic Acids Res. 25:3389-3402.

2. Anzai, Y., Kim, H., Park, J., Wakabayashi, H., and Oyaizu, H. 2000. Phylogenetic affiliation of the pseudomonads based on 16S rRNA sequence. Int. J. Syst. Evol. Microbiol. 50:15631589.

3. Baldani J. I., Pot, B., Kirchhof, G., Falsen, E., Baldani. V. L. D., Olivares F. L., Hoste, B., Kersters, K., Hartmann, A., Gillis, M., and Döbereiner, J. 1996. Emended description of Herbaspirillum; inclusion of [Pseudomonas] rubrisubalbicans, a mild plant pathogen, as Herbaspirillum rubrisubalbicans comb. nov.; and classification of a group of clinical isolates (EF group 1) as Herbaspirillum species 3. Int. J. Syst. Evol. Microbiol. 46:802-810.

4. Baldani, V. L. D., Baldani, J. I., Olivares, F., and Döbereiner, J. 1992. Identification and ecology of Herbaspirillum seropedicae and the closely related Pseudomonas rubrisubalbicans. Symbiosis 13:65-73.

5. Balogh, B., Jones, J. B., Momol, M. T., Olson, S. M., Obradovic, A., King, P., and Jackson, L. E. 2003. Improved efficacy of newly formulated bacteriophages for management of bacterial spot on tomato. Plant Dis. 87:949-954.

6. Bozzola, J. J., and Russell, L. D. 1999. Electron Microscopy: Principles and Techniques for Biologists. Jones and Bartlett Publishers, Sudbury, MA.

7. Cook, A. A., and Stall, R. E. 1963. Inheritance of resistance in pepper to bacterial spot. Phytopathology 53:1060-1062.
8. Ding, L., and Yokota, A. 2004. Proposals of Curvibacter gracilis gen. nov., sp. nov. and Herbaspirillum putei sp. nov. for bacterial strains isolated from well water and reclassification of [Pseudomonas] huttiensis, [Pseudomonas] lanceolata, [Aquaspirillum] delicatum and [Aquaspirillum] autotrophicum as Herbaspirillum huttiense comb. nov., Curvibacter lanceolatus comb. nov., Curvibacter delicatus comb. nov. and Herbaspirillum autotrophicum comb. nov. Int. J. Syst. Evol. Microbiol. 54:2223-2230.

9. Egel, D. S., Graham, J., and Stall, R. E. 1991. Genomic relatedness of Xanthomonas campestris strains causing diseases of citrus. Appl. Environ. Microbiol. 57:2724-2730.

10. Flaherty, J. E., Jones, J. B., Harbaugh, B. K. Somodi, G. C., and Jackson, L. E. 2000. Control of bacterial spot on tomato in the greenhouse and field with $\mathrm{H}$-mutant bacteriophages. HortScience 35:882-884.

11. Hibberd, A. M., Stall, R.E., and Bassett, M. J. 1987. Different phenotypes associated with incompatible races and resistance genes in bacterial spot disease of pepper. Plant Dis. 71:10751078 .

12. Horsfall, J. G., and Barratt, R. W. 1945. An improved system for measuring plant disease. (Abstr.) Phytopathology 35:655.

13. Jones, J. B., Jones, J. P., McCarter, S. M., and Stall, R. E. 1984. Pseudomonas viridiflava : Causal agent of bacterial leaf blight of tomato. Plant Dis. 68:341-342.

14. Jones, J. B., Jones, J. P., Stall, R. E., and Zitter, T. A. 1991. Compendium of Tomato Diseases. The American Phytopathological Society, St. Paul, MN.

15. Jones, J. B., Lacy, G. H., Bouzar, H., Stall, R. E., and Schaad, N.W. 2004. Reclassification of the Xanthomonads associated with bacterial spot disease of tomato and pepper. Syst. Appl. Microbiol. 27:755-762.

16. Leifson, E. 1962. The bacterial flora of distilled and stored water. III. New species of the genera Corynebacterium, Flavobacterium, Spirillum and Pseudomonas. Int. Bull. Bacteriol. Nomencl. Taxon. 12:161-170.

17. Obradovic, A., Jones, J. B., Momol, M. T., Balogh, B., and Olson, S. M. 2004. Management of tomato bacterial spot in the field by foliar applications of bacteiophages and SAR inducers. Plant Dis. 88:736-740.

18. Ponsonnet, C., and Nesme, X. 1994. Identification of Agrobacterium strains by PCR-RFLP analysis of pTi and chromosomal regions. Arch. Microbiol. 161:300-309.

19. Sasser, M. 2001. Identification of Bacteria by Gas Chromatography of Cellular Fatty Acids. Technical note \#101. MIDI, Newark, DE.

20. Schaad, N. W., Jones, J. B., and Chun, W. 2001. Laboratory Guide for Identification of Plant Pathogenic Bacteria. The American Phytopathological Society, St. Paul, MN. 